\title{
Histopathological analysis of benign polyps in patients with carcinoma of the colon and rectum
}

\author{
G. EKELUND AND C. LINDSTRÖM \\ From the Departments of Surgery and Pathology, University of Lund, Malmö General Hospital, Sweden
}

SUMMARY All benign polyps in a 10-year series of 960 patients with colorectal carcinoma from a defined population were analysed. All cases where histological specimens of the polyps were available were reclassified according to morphological type and grade of differentiation. The findings lend support to the assumption of a relationship between benign epithelial neoplasms and adenocarcinoma of the colon and rectum.

Whether adenomas in the colon and rectum are premalignant or not is still a controversial question (Morson and Bussey, 1970; Lane, Kaplan, and Pascal, 1971; Buntain, ReMine, and Farrow, 1972). This is probably due partly to the wide variation in the published frequencies of benign polyps with and without associated carcinoma of the large bowel. This variation may in turn be due to differences in the examination methods, the composition of the materials used, and the classification of the polyps. For instance, metaplastic polyps, which are not neoplastic (Morson, 1962) and therefore irrelevant, are sometimes included as adenomas. Only polyps which can be collectively labelled 'benign epithelial' neoplasms (Morson and Dawson, 1972) are of relevant interest.

A report of a 10-year series of surgically treated cases of colorectal carcinoma in a defined population has recently been published (Berge, Ekelund, Mellner, Pihl, and Wenckert, 1973). The present paper reports a reclassification of those benign colorectal polyps associated with carcinoma in that series.

\section{Materials and Methods}

From 1958 to 1967960 patients with colorectal carcinoma were admitted to the only surgical department in the town of Malmö. A report of that series (Berge et al, 1973) included the overall frequency, site, and size distribution of coexisting benign colorectal polyps. Only polyps demonstrably present at the time of diagnosis or surgical treatment of the carcinoma were considered. The polyps were sought with one or more of the following methods: radioReceived for publication 2 May 1974. graphy with the double-contrast method, rectoscopy, and examination of the operative as well as the necropsy specimens of patients who had died within 30 days of operation for colorectal carcinoma. That part of the bowel removed at operation or at necropsy was rinsed with water, after which it was examined macroscopically for polyps. As a rule, the size of the polyps could be estimated only from the patients' records. Definitions of borderlines between the rectum, left colon, and right colon were given. Carcinomas on the basis of familial adenomatosis or ulcerative colitis were not included (Berge et al, 1973).

A reinvestigation of the above series for the present purpose resulted in minor differences in overall frequency, localization, and size of the polyps associated with carcinoma. Polyps were found in 215 patients (132 men and 83 women), ie, in $22 \%$ of the 960 patients. The 215 patients, with a median age of $65-69$, had in all 471 polyps (table I). Most patients had at most four polyps, but only one patient had as many as 21 polyps.

The present material consisted of 381 polyps. The remaining 90 polyps in the basic material could not be analysed owing to lack of histopathological specimens. These 90 polyps had not been examined

\begin{tabular}{cc}
\hline Number of Polyps & Number of Patients \\
\hline 1 & 109 \\
2 & 51 \\
$3-5$ & 41 \\
$6-10$ & 12 \\
$>10$ & 2 \\
\hline
\end{tabular}

Table I Number of patients with various number of polyps 


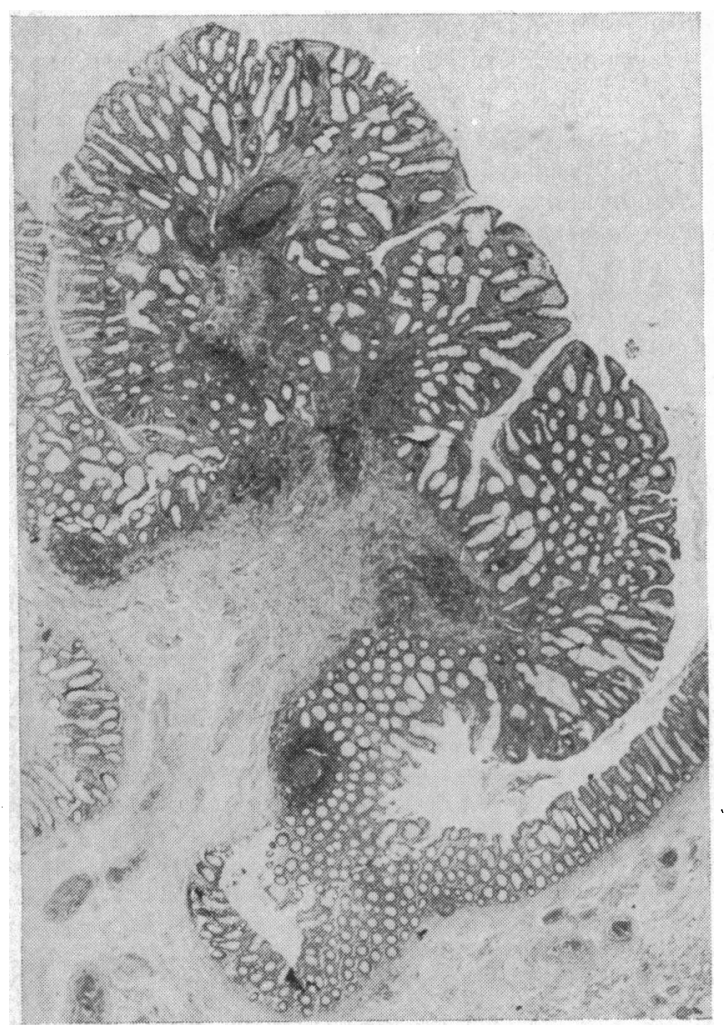

Fig 1a Adenomatous polyp ( $H$ and $E \times 15)$

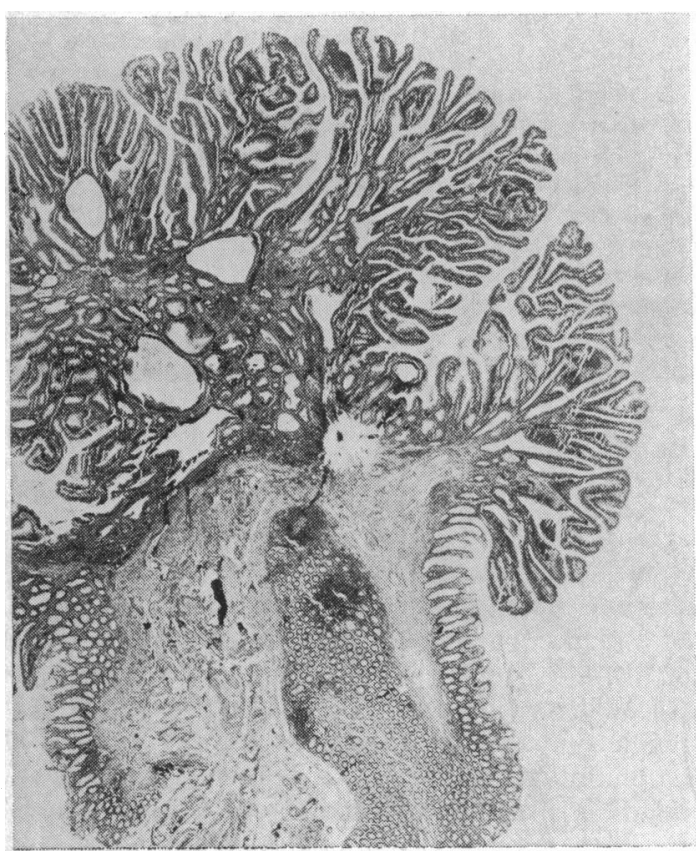

Fig 1b Adenovillous polyp ( $H$ and $E \times 11)$ microscopically and had been diagnosed only radiologically (22), gross examination at necropsy (64), or by the surgeon (4).

Histological sections, stained with haematoxylineosin, were examined, and one month later reexamined, by one pathologist. The examiner was unaware of the case from which a given section had been obtained as well as of the gross appearance and the site of the polyp. Good agreement was later found between the results of the two examinations. Tumours with varying grades of differentiation within the same lesion were classified according to the part with the poorest differentiation.

Unless otherwise stated, the word 'polyp' is to be understood clinically as designating any mass of

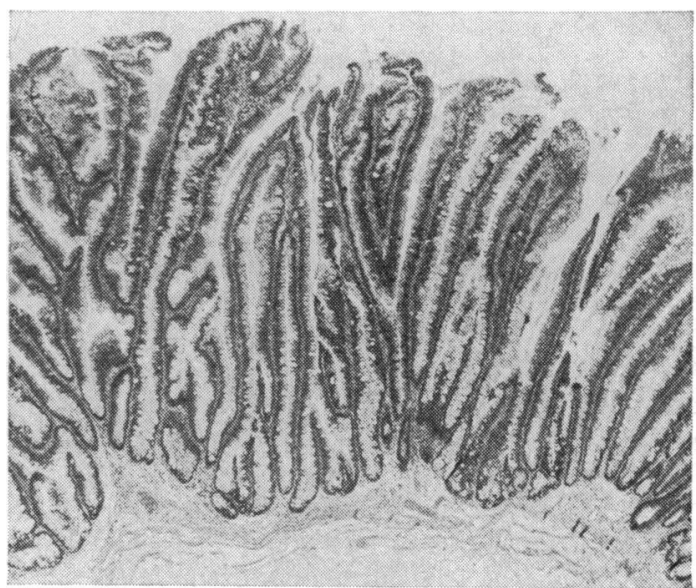

Fig 1c Adenovillous papilloma ( $H$ and $E \times 28)$

tissue projecting from the surface of the mucosa and in histopathological descriptions as a circumscribed, rounded, often pedunculated tumour.

\section{Morphological Types of Polyps}

BENIGN EPITHELIAL NEOPLASMS

The following three types of benign epithelial neoplasms were distinguished.

Adenomatous polyps (simple adenomas)

These are circumscribed, rounded, often pedunculated adenomatous tumours built up of closely packed, epithelial tubules and with a smooth or somewhat lobular surface with intervening clefts (fig 1a).

Adenovillous polyps

These have the same features as adenomatous polyps but with mainly villous surface (fig $1 \mathrm{~b}$ ). 


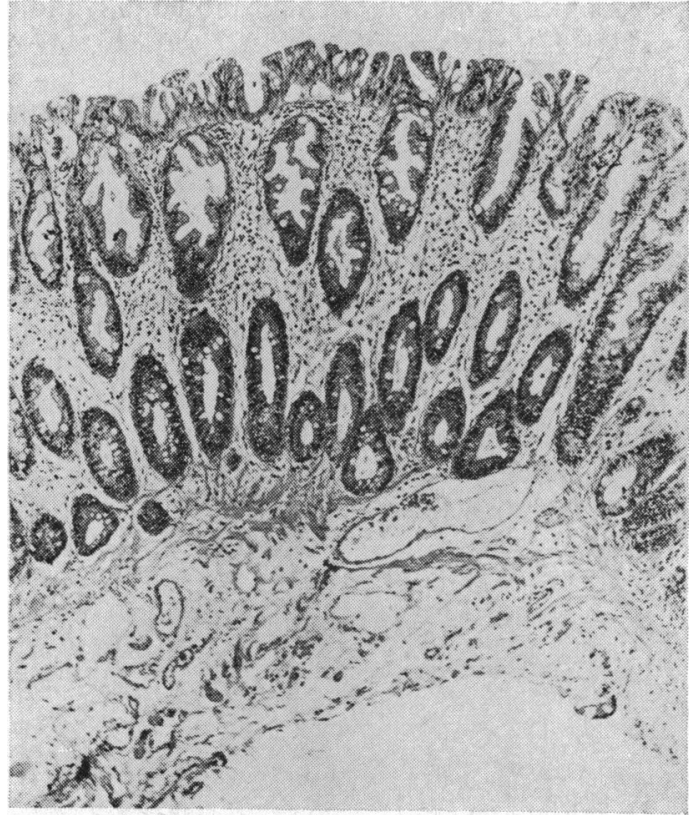

Fig 2 Part of metaplastic polyp ( $H$ and $E \times 70)$

\section{Adenovillous papillomas}

These are mainly sessile tumours of a basically papillary structure and usually with a villous surface (fig 1c).

METAPLASTIC (HYPERPLASTIC) POLYPS

Polyps of non-neoplastic type (Morson, 1962) with glandular forms lined with metaplastic, slightly eosinophilic epithelium alternating with evenly distributed goblet cells and bulging into the lumina of the glands, giving them a stellate appearance (fig 2).

MISCELLANEOUS BENIGN POLYPOID TUMOURS Amongst others are mesenchymal tumours, such as lipoma and lymphatic polyps, and fibroepithelial polyps (mucosal tags).

\section{Grades of Differentiation of Benign Epithelial Neoplasms}

Well differentiated have glands and epithelium closely resembling the glands and epithelium of normal colonic mucosa and no appreciable atypia of the epithelium. They show regular nuclear polarity and largely normal production of mucus by the epithelium (fig 3a).

Well to moderately differentiated are of intermediate grade.

Moderately differentiated have a somewhat less pronounced tendency to differentiate, with more closely packed epithelial cells and slightly irregular positions of the nuclei. Moderate mucus production is demonstrable, and there is a slight increase in mitotic frequency (fig $3 b$ ).

Moderately to poorly differentiated are those showing moderately atypical epithelium with somewhat abnormal nuclear polarity, a moderate number of apical mucus vacuoles in the cells, and a moderately increased number of mitotic figures (fig $3 c$ ).

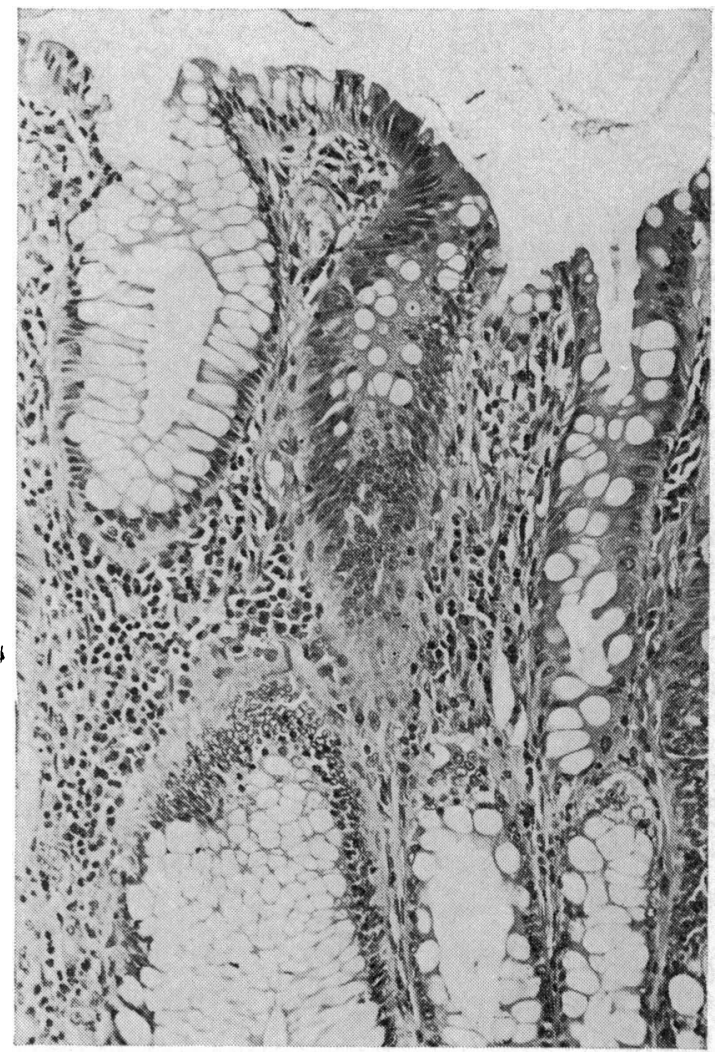

Fig 3a Well differentiated $(H$ and $E \times 178)$

Poorly differentiated polyps have a closely packed, atypical, basophilic columnar epithelium with no secretion vacuoles, slight irregular nuclear polarity, and a markedly increased number of mitotic figures (fig 3d).

In advanced dysplasia there are often somewhat irregularly shaped glands, lined with strongly atypical basophilic, tightly packed epithelial cells with irregularly placed nuclei, numerous mitotic figures, and thus cellular atypia sufficient to warrant a diagnosis of carcinoma (fig 3e) but no bridging by 


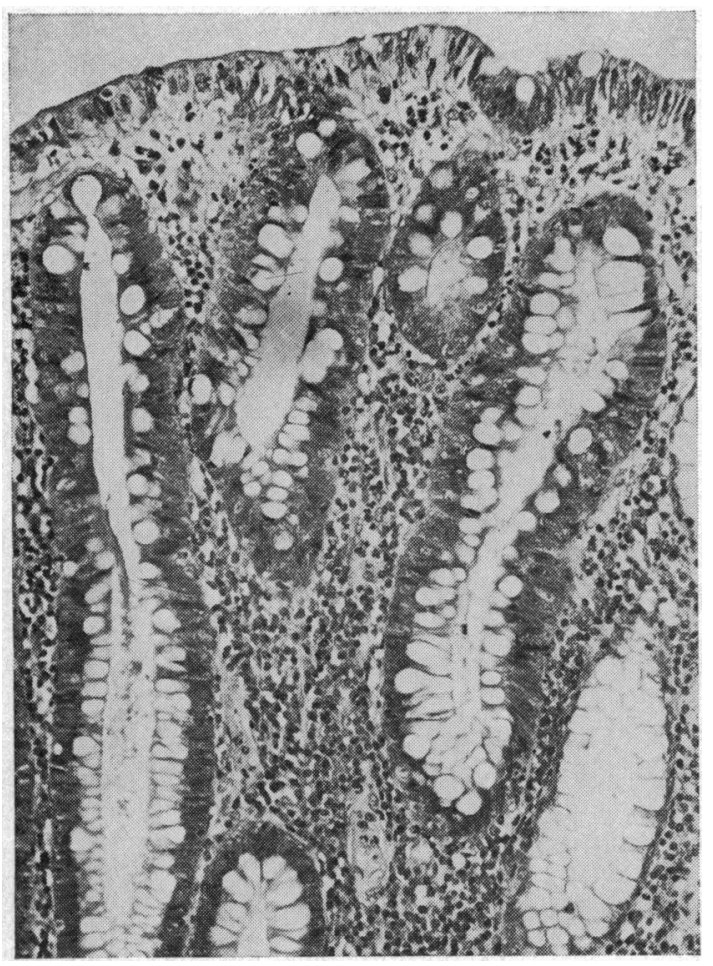

Fig $3 \mathrm{~b}$ Moderately differentiated ( $H$ and $E \times 178$ )

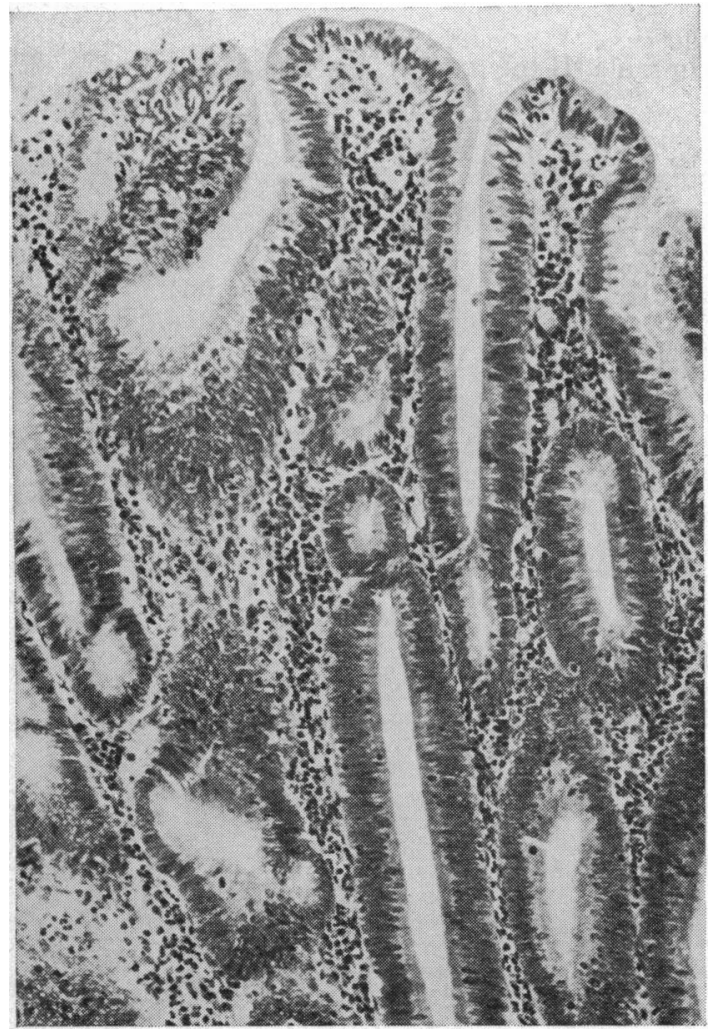

Fig 3d Poorly differentiated ( $H$ and $E \times 178$ )

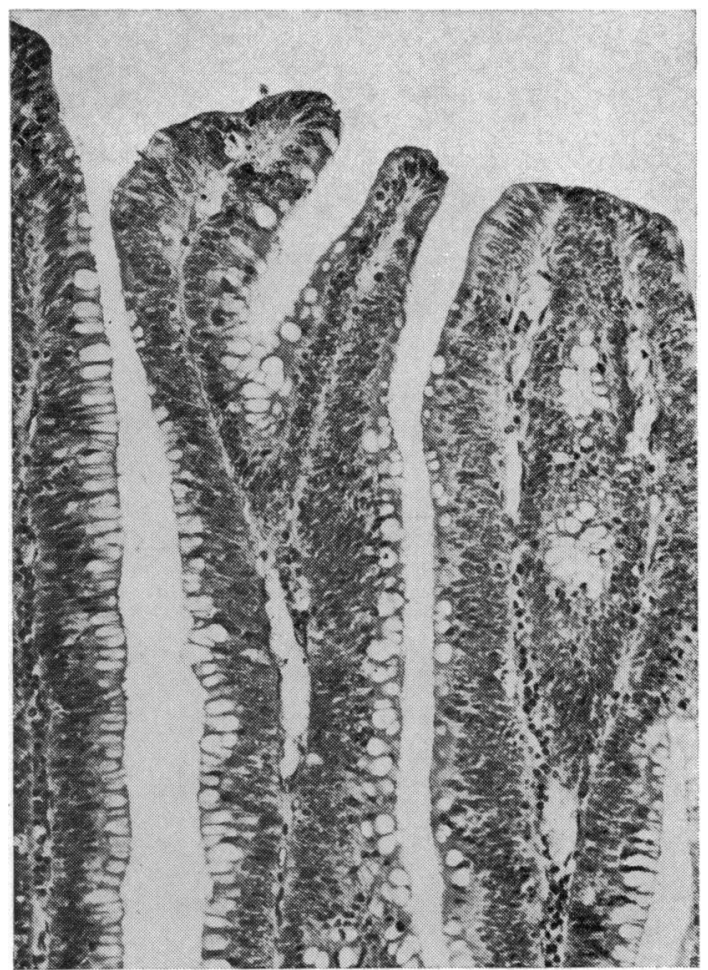

Fig 3c Moderately topoorly differentiated (HandE $\times 178$ )

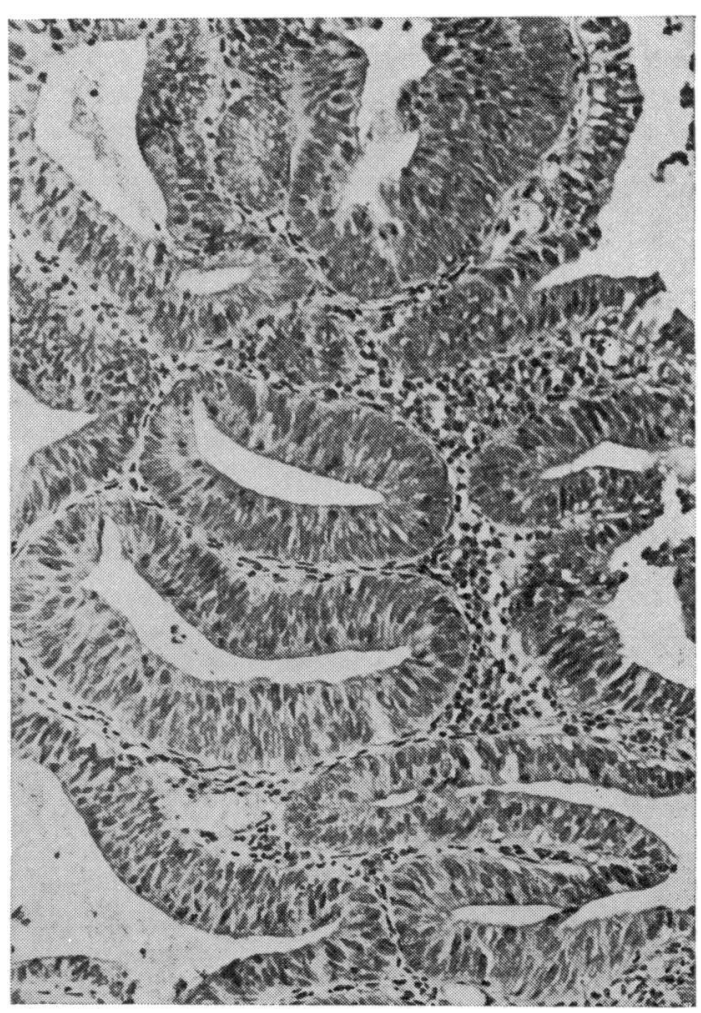

Fig $3 \mathrm{e}$ Advanced dysplasia ( $H$ and $E \times 178$ )

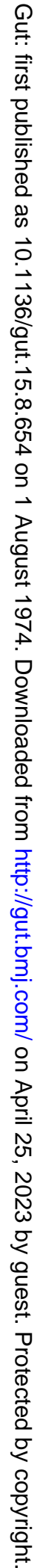




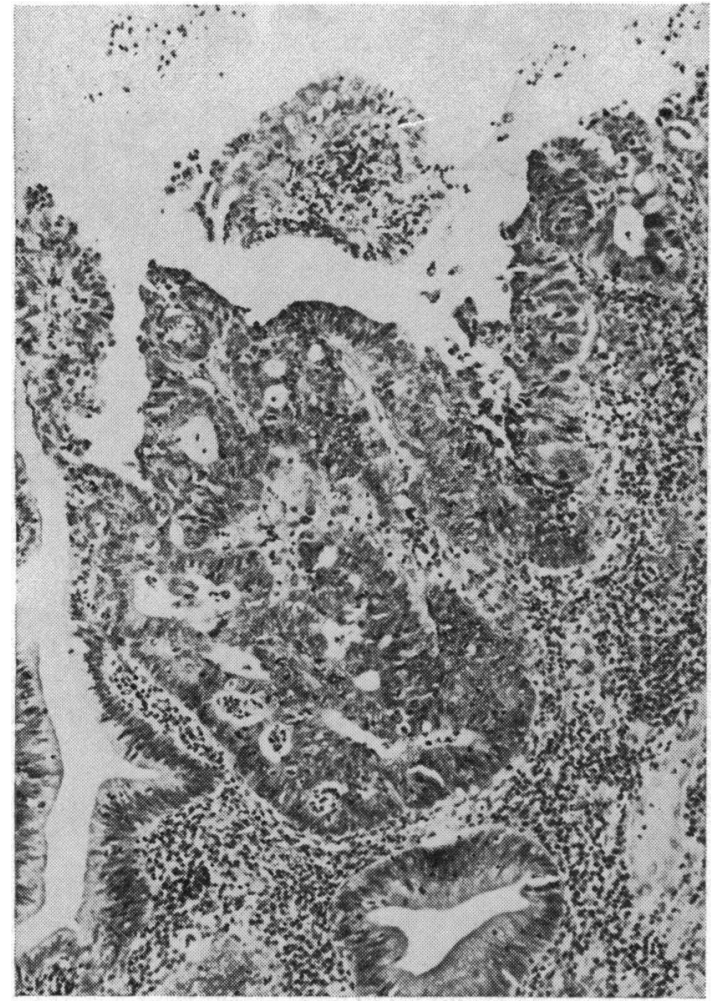

Fig 4 Advanced dysplasia with cribrous formations ( $H$ and $E \times 119)$

\begin{tabular}{lrcl}
\hline Morphological Type & \multicolumn{3}{l}{ Number of Lesions } \\
\cline { 2 - 4 } & Men & Women & Total \\
\hline Adenomatous polyp & 153 & 85 & $238(77 \%)$ \\
Adenovillous polyp & 36 & 28 & $64(21 \%)$ \\
Adenovillous papilloma & 4 & 2 & $6(2 \%)$ \\
\hline
\end{tabular}

Table II Different morphological types of benign epithelial neoplasms

the epithelium, so-called cribrous formations, which were regarded as signs of definitive carcinoma (fig 4). In the present investigation adenomatous tumours with these forms were grouped with infiltrating adenocarcinomas.

\section{Results}

Of the 381 polyps available for histological review, $308(81 \%)$ were benign epithelial neoplasms, 46 $(12 \%)$ metaplastic, and $27(7 \%)$ were of miscellaneous types.

\section{BENIGN EPITHELIAL NEOPLASMS}

Table II gives the morpholigical classification and sex distribution. Almost one fourth of all benign epithelial neoplasms were adenovillous lesions; of the former, $63 \%$ were found in men and $37 \%$ in women.

In table III the tumours are grouped according to

\begin{tabular}{llll}
\hline Morphological Type & \multicolumn{1}{l}{ Size } & & \\
\cline { 2 - 4 } & $<5 \mathrm{~mm}$ & $5-10 \mathrm{~mm}$ & \multicolumn{1}{c}{$10 \mathrm{~mm}$} \\
\cline { 2 - 4 } & $\mathrm{Number}$ & Number & Number \\
\hline Adenomatous polyp & $159(88 \%)$ & $42(67 \%)$ & $25(51 \%)$ \\
Adenovillous polyp & $22(12 \%)$ & $19(30 \%)$ & $20(41 \%)$ \\
Adenovillous papilloma & - & $2(3 \%)$ & $4(8 \%)$
\end{tabular}

Table III Size distribution of different morphological types of benign epithelial neoplasms

\begin{tabular}{|c|c|c|c|}
\hline \multirow[t]{2}{*}{ Site } & \multirow{2}{*}{$\begin{array}{l}\text { Adenomatous } \\
\text { Polyp } \\
\text { Number }\end{array}$} & \multirow{2}{*}{$\begin{array}{l}\text { Adenovillous Polyp } \\
\text { or Papilloma } \\
\text { Number }\end{array}$} & \multirow{2}{*}{$\begin{array}{l}\begin{array}{l}\text { Metaplastic } \\
\text { Polyp }\end{array} \\
\text { Number }\end{array}$} \\
\hline & & & \\
\hline $\begin{array}{l}\text { Caecum } \\
\text { Ascending colon } \\
\text { Transverse colon (including flexures) } \\
\text { Descending colon } \\
\text { Sigmoid colon } \\
\text { Rectum }\end{array}$ & $\begin{array}{l}14(6 \%) \\
61(26 \%) \\
27(11 \%) \\
22(9 \%) \\
63(27 \%) \\
51(21 \%)\end{array}$ & $\begin{array}{l}4(6 \%) \\
16(23 \%) \\
8(11 \%) \\
7(10 \%) \\
15(21 \%) \\
20(29 \%)\end{array}$ & $\begin{array}{l}1(2 \%) \\
3(7 \%) \\
3(7 \%) \\
-10(22 \%) \\
28(62 \%)\end{array}$ \\
\hline
\end{tabular}

Table IV Distribution by site of adenomatous polyps, adenovillous lesions, and metaplastic polyps 

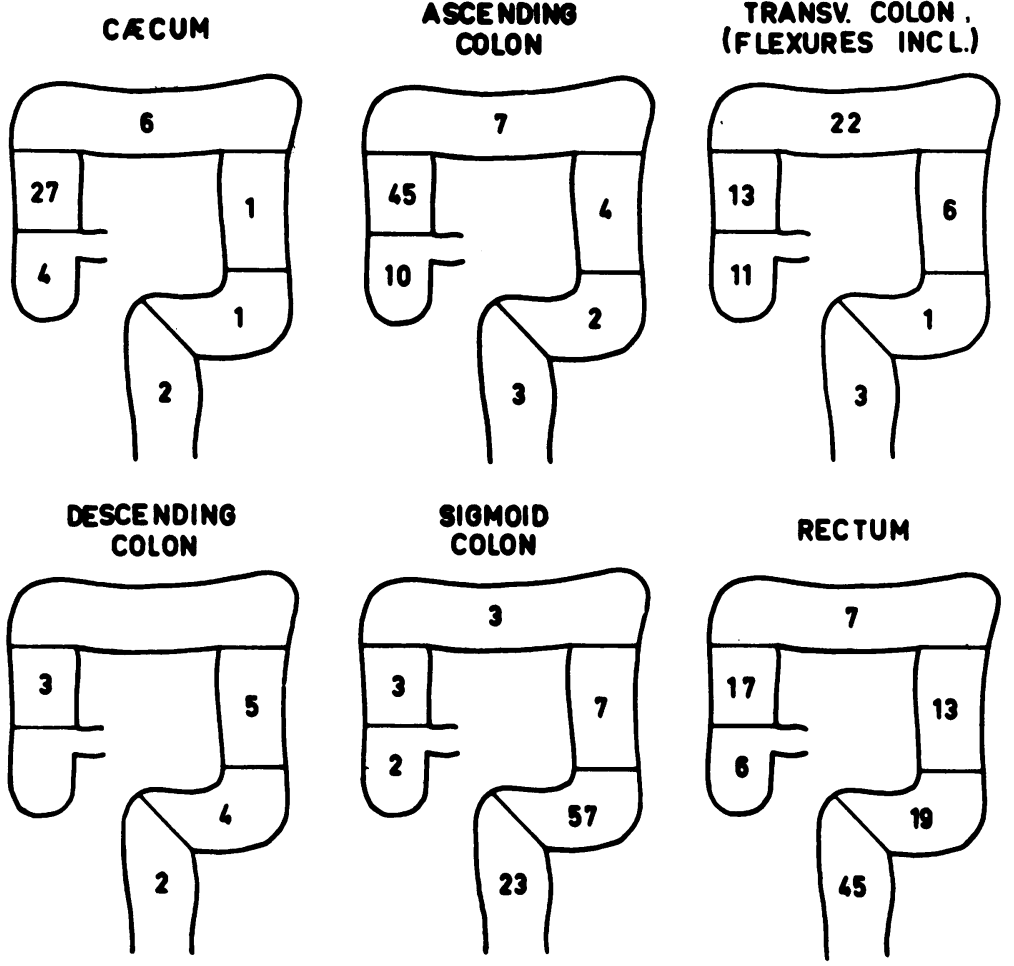

Fig 5 Localization of benign epithelial neoplasms according to the localization of the coexisting carcinoma. The figures represent the various sites of the carcinomas. In patients with more than one carcinoma the polyp is assigned to each of the segments involved by the carcinoma size and morphological type. Adenovillous lesions were relatively more common among the larger lesions.

Table IV gives the distributions by site of adenomatous polyps and adenovillous lesions; they were similar. In the men, $54 \%$ of the polyps were seen in the sigmoid colon and rectum compared with only $38 \%$ in the women.

Figure 5 shows the distribution according to the site of the coexisting carcinoma. It is clear that the benign epithelial neoplasms tended to be situated in the vicinity of the coexisting carcinoma.
In table $\mathrm{V}$ adenomatous polyps and adenovillous lesions are distributed according to grades of differentiation. Most $(77 \%)$ of the adenovillous lesions were poorer than moderately differentiated. The corresponding figure for adenovillous polyps only was $78 \%$. Of benign epithelial neoplasms in the men $65 \%$ were less than moderately differentiated; the corresponding figure in the women was $57 \%$.

Table VI shows that the differentiation of benign epithelial neoplasms tended to be poorer with decreasing distance from the anus, and table VII, with increasing size of the lesion. Of the 36 benign

\begin{tabular}{|c|c|c|c|c|}
\hline \multirow[t]{3}{*}{ Grade of Differentiation } & \multirow{3}{*}{$\begin{array}{l}\text { Adenomatous } \\
\text { Polyp } \\
\text { Number }\end{array}$} & \multirow{3}{*}{$\begin{array}{l}\text { Adenovillous } \\
\text { Polyp or } \\
\text { Papilloma } \\
\text { Number }\end{array}$} & \multicolumn{2}{|l|}{ Total } \\
\hline & & & Men & Women \\
\hline & & & Number & Number \\
\hline $\begin{array}{l}\text { Well differentiated } \\
\text { Well to moderately differentiated } \\
\text { Moderately } \\
\text { Moderately to poorly differentiated } \\
\text { Poorly differentiated } \\
\text { Advanced dysplasia }\end{array}$ & $\begin{array}{l}26(11 \%) \\
28(12 \%) \\
47(20 \%) \\
81(34 \%) \\
43(18 \%) \\
13(6 \%)\end{array}$ & $\begin{array}{l}1(1 \%) \\
5(7 \%) \\
10(14 \%) \\
26(37 \%) \\
18(26 \%) \\
10(14 \%)\end{array}$ & $\begin{array}{l}19(10 \%) \\
16(8 \%) \\
33(17 \%) \\
68(35 \%) \\
40(21 \%) \\
17(9 \%)\end{array}$ & $\begin{array}{l}8(7 \%) \\
17(15 \%) \\
24(21 \%) \\
39(34 \%) \\
21(18 \%) \\
6(5 \%)\end{array}$ \\
\hline
\end{tabular}

Table V Grade of differentiation for adenomatous polyps and adenovillous lesions 


\begin{tabular}{|c|c|c|c|}
\hline \multirow[t]{2}{*}{ Grade of Differentiation } & Right Colon & Left Colon & Rectum \\
\hline & Number & Number & Number \\
\hline $\begin{array}{l}\text { Well or moderately differentiated } \\
\text { Poorer than moderately differentiated }\end{array}$ & $\begin{array}{l}58(46 \%) \\
69(54 \%)\end{array}$ & $\begin{array}{l}38(35 \%) \\
72(65 \%)\end{array}$ & $\begin{array}{l}22(31 \%) \\
49(69 \%)\end{array}$ \\
\hline
\end{tabular}

Table VI Grade of differentiation according to site of benign epithelial neoplasms

\begin{tabular}{|c|c|c|c|}
\hline \multirow[t]{3}{*}{ Grade of Differentiation } & \multicolumn{3}{|l|}{ Size } \\
\hline & $<5 \mathrm{~mm}$ & $5-10 \mathrm{~mm}$ & $>10 \mathrm{~mm}$ \\
\hline & Number & Number & Number \\
\hline $\begin{array}{l}\text { Well or moderately differentiated } \\
\text { Poorer than moderately differentiated }\end{array}$ & $\begin{aligned} 80(44 \%) \\
101(56 \%)\end{aligned}$ & $\begin{array}{l}19(30 \%) \\
44(70 \%)\end{array}$ & $\begin{array}{l}13(27 \%) \\
36(73 \%)\end{array}$ \\
\hline
\end{tabular}

Table $\mathrm{VII}_{\perp}$ Grade of differentiation according to size of benign epithelial neoplasms

epithelial neoplasms greater than $10 \mathrm{~mm}$ and less than moderately differentiated, 17 were adenomatous polyps and 19 adenovillous lesions.

The relative frequency of polyps with severe atypia situated in the vicinity of the coexisting carcinoma and in other parts, respectively, could be estimated only in cases with a solitary polyp and a solitary coexisting carcinoma. It was found that $37 \%$ of the polyps in the same segment as the coexisting carcinoma, $29 \%$ of those in an adjacent segment and $27 \%$ of those in other segments were either poorly differentiated or showed advanced dysplasia.

\section{METAPLASTIC POLYPS}

Forty-six metaplastic polyps were found in 26 patients (15 men and 11 women). These constituted $12 \%$ of the histologically verified polyps. Twentythree of these polyps were seen in men and 23 in women. Thirty were found in cases with a solitary carcinoma and 16 in cases with multiple carcinomas. None of the metaplastic polyps were found in patients below 50 years of age. Eighty-four per cent of the metaplastic polyps were found in the sigmoid colon or rectum (table IV). All of the 44 polyps of known size were less than $5 \mathrm{~mm}$ in diameter except one, which was 5-10 mm across. Metaplastic polyps were associated with other types of benign polyp in all cases except two.

\section{MISCELLANEOUS POLYPS}

Of the 27 polyps of other types, 20 were lesions with microscopically normal mucosa (mucosal tags), while three were inflammatory and four were mesenchymal.

\section{Discussion}

Several authors report comparatively high fre- quencies of colorectal polyps. This is probably explained by differences in examination technique, eg, the use of a magnifying glass (Atwater and Bargen, 1945) or by a closer examination of certain regions, especially the rectum (Enquist, 1957; Horn, 1971). Some authors, who have studied only very small polyps, ie, polyps less than $2 \mathrm{~mm}$ (Arthur, 1962) or less than $3 \mathrm{~mm}$ (Lane et al, 1971) in diameter, have found remarkably high percentages of metaplastic polyps, while others, who have used routine methods only, have found lower percentages. Silverberg (1970), for instance, found metaplastic (hyperplastic) polyps in $10.6 \%$ of 500 surgical specimens and Hultborn (1952) found $9.7 \%$ hyperplastic lesions in his series of 93 benign epithelial tumours.

In the present material only ordinary clinical routine methods were used for the detection of polyps. The findings in this material can therefore probably be regarded as fairly representative of what might be expected in ordinary hospital series, especially as the parent material consisted of $94 \%$ of all cases of colorectal carcinoma diagnosed during life in a defined population.

\section{MORPHOLOGICAL CLASSIFICATION}

A variety of names are in use to designate the different types of benign epithelial neoplasms. Adenoma by definition means a benign neoplastic tumour with glandular patterns or composed of epithelium derived from glandular mucosa and is therefore in the colon and rectum synonymous with benign epithelial neoplasm in the sense used in this investigation. In this study the term benign epithelial neoplasm was preferred to adenoma as a collective name, because the latter term often seems to be reserved in practice for the simple adenoma. The adenomas range from pure adenomatous polyps (simple adenomas) through adenomatous polyps 
with villous surfaces to typical villous papillomatous adenomas. These different types of adenoma are biologically essentially similar and it is often difficult to decide to which subgroup a given polyp belongs (Morson and Dawson, 1972). In the present paper the following descriptive histopathological names were used: 'adenomatous polyp', 'adenovillous polyp', and 'adenovillous papilloma'.

The term 'adenomatous polyp' is thus used to designate the most common variant, which is usually a smooth, rounded, circumscribed lesion built up of densely packed epithelial tubules (Anderson, 1967; Cappell and Anderson, 1971; Morson and Dawson, 1972).

The term 'adenovillous polyp' was chosen for the intermediate group in order to describe histologically a polypoid lesion with a basically adenomatous structure but a mainly villous surface. In the literature many synonyms have been used for this type, eg, villous polyadenoma (Potet and Soullard, 1971), villoglandular polyp (Welin, Youker, Spratt, Linnell, Spjut, Johnson, and Ackerman, 1963), papillary adenoma (McColl, 1970; Morson and Dawson, 1972).

The term 'adenovillous papilloma' for the third type of lesion was used to describe not only the architecture of the growth, but also the type of epithelium and was therefore in conformity with the terminological principles used here. In the literature the term 'papillary adenoma' (see above) has been used for this type of lesion (Grinnell and Lane, 1958). Anderson (1967) and Ackerman and Butcher (1968) used papillary adenoma and villous adenoma as synonyms. Another common name used for this type of lesion is villous papilloma (Morson and Dawson, 1972).

\section{GRADING}

Like adenocarcinoma, benign epithelial neoplasms can be graded histopathologically according to the histological structure of the glands and the character of the lining epithelium (Potet and Soullard, 1971). The grading used in the present investigation corresponds to that used at the Department of Pathology in Malmö and corresponds largely to that used by Potet and Soullard (1971). In practice, the grade of differentiation of a tumour must be based on the glandular architecture and, above all, on the degree of differentiation of the epithelium.

The borderlines between the grades are of course not distinct and classification is often difficult, and especially as pointed out by Potet and Soullard (1971), between poor differentiation and advanced dysplasia ('cytologic carcinoma in situ'). The grading used here was only a practical attempt to measure the cytological and histological changes seen. This must be borne in mind in any relevant discussion of the pathogenesis of cancer. No clear correlation can exist between the grades of this scale and the premalignant behaviour of the lesions because, for instance, epithelial cells in infiltrating carcinomas can be well differentiated. Generally speaking, however, it appears that premalignancy is morphologically more conspicuous with increasing loss of differentiation of the benign epithelial neoplasms.

\section{BENIGN EPITHELIAL NEOPLASMS}

The classification of the polyps in the present material according to morphological types revealed that most of the polyps with coexisting carcinoma were benign epithelial neoplasms.

In the parent material, the distribution within the colon and rectum of benign polyps (of all kinds) paralleled that of carcinomas, though carcinomas were relatively somewhat more common $(67 \%)$ than benign polyps $(52 \%)$ in the rectum and sigmoid colon (Berge et al, 1973). The exclusion of metaplastic and non-epithelial polyps does not mean any obvious difference in the relative distribution of the remaining polyps; $48 \%$ of the benign epithelial neoplasms were thus found in the rectum and sigmoid colon. The similarity was most evident in the men. Though the relative distributions within the colonrectum of benign epithelial neoplasms and carcinomas were not quite identical, we regarded them as similar enough to warrant the assumption of an interrelationship.

Another interesting observation in the present material was that the closer the benign epithelial neoplasms to the anus the relatively poorer were their differentiation. This, together with the fact that the majority of carcinomas were situated in the sigmoid colon and rectum, might lend support to the assumption of a relationship between benign epithelial neoplasm and adenocarcinoma. Winblad and Friberg (1956) also found that more atypical polyps tended to occur more frequently in the left part of the colon. They, however, as a criterion for classification, used the percentage of the circumference of the lesions that had atypical epithelium.

In the present material adenomatous polyps were distinguished from adenovillous lesions. These growths did not differ in distribution within the colon-rectum. It is generally agreed that adenovillous papillomas have a greater malignant potential than other benign epithelial neoplasms (Lane and Lev, 1963). Fung and Goldman (1970), in a prospective analysis, showed that focal villous changes in adenomatous polyps were commoner than previously supposed. They found such changes in $35 \%$ of solitary adenomatous polyps and in as many as 
$75 \%$ of lesions larger than $10 \mathrm{~mm}$ in diameter. Fung and Goldman (1970) also stated that 'although morphologically the adenomatous polyp with focal villous change appears to represent an intermediate form between the pure adenomatous polyp and the villous adenoma, evidence for obligatory transformation and increased malignant potential of this form is inconclusive'. In the present material the differentiation was generally poorer for adenovillous polyps than for adenomatous polyps. This finding may suggest an increased malignant potential even in adenovillous polyps.

As in the material of Potet and Soullard (1971), there appeared to be a correlation between the tumour size and grade of differentiation, ie, the larger the benign epithelial neoplasm the poorer the differentiation.

Several authors (Rider, Kirsner, Moeller, and Palmer, 1954; Ekelund, 1963) have reported that men are more prone to develop polyps than women. In the present material this finding was confirmed, as $62 \%$ of the patients with polyps were men. Of all benign epithelial neoplasms, $63 \%$ occurred in the men compared with $37 \%$ in the women. It is also interesting that in the men they tended to be less well differentiated than those in women.

Kalus (1972) found carcinoma in situ in adenomatous polyps to be commoner in the presence than in the absence of coexisting adenocarcinomatous lesions, and to be commonest $(47 \%)$ when the adenomatous polyp and the associated carcinoma were situated in the same segment of the large bowel. In the present series a similar analysis was made of solitary benign epithelial neoplasms associated with a solitary adenocarcinoma. The relative frequency of such polyps showing either advanced dysplasia or being poorly differentiated was highest when the polyps were situated in the same segment as the coexisting carcinoma. These findings may suggest a local increased susceptibility of the large bowel to adenocarcinoma.

\section{METAPLASTIC POLYPS}

Metaplastic (hyperplastic) polyps were already described in 1927 by Schmieden and Westhues and have later been regarded as not neoplastic and without any malignant potential (Morson, 1962). It is therefore justified to exclude them from series of benign epithelial neoplasms and deal with them separately. However, before Morson (1962), Arthur (1962), and Lane and Lev (1963) described the significance and properties of metaplastic polyps in fair detail, such lesions were often included in published series of polyps. Also in some later investigations, eg, those of Potet and Soullard (1971), the metaplastic lesions have been included as adenomas.
Metaplastic polyps are regarded as manifestations of degeneration of the mucosa and a phenomenon of aging (Arthur, 1968). In the present investigation the metaplastic polyps were localized mainly to the rectum and sigmoid colon, as in earlier investigations (Morson, 1962). These polyps are generally small and usually less than $5 \mathrm{~mm}$ in diameter (Arthur, 1968; Goldman, Ming, and Hickok, 1970). In the present material there was only one metaplastic polyp $5-10 \mathrm{~mm}$ in diameter and none more than $10 \mathrm{~mm}$.

\section{Conclusions}

The findings in the present material of benign polyps in patients with adenocarcinoma of the colon and rectum suggest that: (1) in routine practice at least three out of four polyps are benign epithelial neoplasms and at least one out of 10 is metaplastic; (2) three out of four benign epithelial neoplasms are adenomatous polyps, the rest adenovillous polyps or papillomas; (3) the distribution by site is similar to that of carcinoma; (4) benign epithelial neoplasms tend to be situated in the vicinity of the coexisting carcinoma; (5) the grade of differentiation of benign epithelial neoplasms tends to vary as $(a)$ the nearer the polyp to the anus, the larger the polyp, and the nearer a solitary polyp to a coexisting solitary carcinoma, the poorer the differentiation and $(b)$ the differentiation is on the average poorer if the lesion is adenovillous; $(c)$ the differentiation is on the average poorer in men than in women; (6) Metaplastic polyps rarely exceed $5 \mathrm{~mm}$ in diameter and are found mostly in the rectum and sigmoid colon.

References

Ackerman, L. V., and Butcher, H. R., Jr. (1968). Surgical Pathology, 4th ed. Mosby, St. Louis.

Anderson, W. (1967). Boyd's Pathology for the Surgeon, 8th ed. Saunders, Philadelphia and London.

Arthur, J. F. (1962). The significance of small mucosal polyps of the rectum. Proc. roy. Soc. Med., 55, 703-704.

Arthur, J. F. (1968). Structure and significance of metaplastic nodules in the rectal mucosa. J. clin. Path., 21, 735-743.

Atwater, J. S., and Bargen, J. A. (1945). The pathogenesis of intestinal polyps. Gastroenterology, 4, 395-408.

Berge, T., Ekelund, G., Mellner, C., Pihl, B., and Wenckert, A. (1973). Carcinoma of the colon and rectum in a defined population. An epidemiological, clinical and postmortem investigation of colorectal carcinoma and coexisting benign polyps in Malmö, Sweden. Acta chir. scand., Suppl. 438.

Buntain, W. L., ReMine, W. H., and Farrow, G. M. (1972). Premalignancy of polyps of the colon. Surg. Gynec. Obstet., 134, 499-508.

Cappell, D. F., and Anderson, J. R. (1971). Muir's Textbook of Pathology, 9th ed. Arnold, London.

Ekelund, G. (1963). On cancer and polyps of colon and rectum. Acto path. microbiol. scand., 59, 165-170.

Enquist, I. F. (1957). The incidence and significance of polyps of the colon and rectum. Surgery, 42, 681-688.

Fung, C. H. K., and Goldman, H. (1970). The incidence and significance of villous change in adenomatous polyps. Amer. J. clin. Path., 53, 21-25. 
Goldman, H., Ming, S., and Hickok, D. F. (1970). Nature and significance of hyperplastic polyps of the human colon. Arch. Path., 89, 349-354.

Grinnell, R. S., and Lane, N. (1958). Benign and malignant adenomatous polyps and papillary adenomas of the colon and rectum. An analysis of 1,856 tumors in 1,335 patients. Int. Abstr. Surg., 106, 519-538.

Horn, R. C., Jr. (1971). Malignant potential of polypoid lesions of the colon and rectum. Cancer (Philad.), 28, 146-152.

Hultborn, K. A. (1952). Cancer of the colon and rectum. A clinical and pathological study with special reference to the possibilities of improving the diagnostic methods and the therapeutic results in adenocarcinoma. Acta chir. scand., Suppl. 172.

Kalus, M. (1972). Carcinoma and adenomatous polyps of the colon and rectum in biopsy and organ tissue culture. Cancer (Philad.), 30, 972-982.

Lane, N., Kaplan, H., and Pascal, R. R. (1971). Minute adenomatous and hyperplastic polyps of the colon: divergent patterns of epithelial growth with specific associated mesenchymal changes. Contrasting roles in the pathogenesis of carcinoma. Gastroenterology, 60, 537-551.

Lane, N., and Lev, R. (1963). Observations on the origin of adenomatous epithelium of the colon. Serial section studies of minute polyps in familial polyposis. Cancer (Philad.), 16, 751-764.

McColl, I. (1970). The pathology and treatment of polyps of the colon and rectum. Ann. roy. Coll. Surg. Engl., 47, 245-259.

Morson, B. C. (1962). Precancerous lesions of the colon and rectum. Classification and controversial issues. J. Amer. med. Ass.,
179, 316-321.

Morson, B. C. (1962). Some peculiarities in the histology of intestinal polyps. Dis. Colon. Rect., 5, 337-344.

Morson, B. C., and Bussey, H. J. R. (1970). Predisposing Causes of Intestinal Cancer (Current Problems in Surgery, 1970). Year Book Medical Publishers, Chicago.

Morson, B. C., and Dawson, I. M. P. (1972). Gastrointestinal Pathology. Blackwell, Oxford.

Potet, F., and Soullard, J. (1971). Polyps of the rectum and colon. Gut, 12, 468-482.

Rider, J. A., Kirsner, J. B., Moeller, H. C., and Palmer, W. L. (1954). Polyps of the colon and rectum. Their incidence and relationship to carcinoma. Amer. J. Med., 16, 555-564.

Schmieden, V., and Westhues, H. (1927). Zur Klinik und Pathologie der Dickdarmpolypen und deren klinische und pathologischanatomischen Beziehungen zum Dickdarmkarzinom. Dtsch. Z. Chir., 202, 1-124.

Silverberg, S. G. (1970). Focally malignant adenomatous polyps of the colon and rectum. Surg. Gynec. Obstet., 131, 103-114.

Welin, S., Youker, J., Spratt, J. S., Jr., Linnell, F., Spjut, H. J., Johnson, R. E., and Ackerman, L. V. (1963). The rates and patterns of growth of 375 tumors of the large intestine and rectum observed serially by double contrast enema study (Malmö technique). Amer. J. Roentgenol., 90, 673-687.

Winblad, S., and Friberg, S. (1956). Observations on the pathology of polyps of the colon. Acta path. microbiol. scand., Suppl. 111, 89-92.

\section{The July 1974 Issue}

\section{THE JULY 1974 ISSUE CONTAINS THE FOLLOWING PAPERS}

Interpretation of fluctuation of transmural potential difference across the proximal small intestine DAVID WINGATE, ROGER GREEN, JOHN SYMES, AND MARIANNE PILOT

Faecal fat excretion after truncal, selective, and highly selective vagotomy for duodenal ulcer J. P. EDWARDS, P. J. LYNDON, R. B. SMITH, AND D. JOHNSTON

Serum gastrin and gastric acid responses to meals at various $\mathrm{pH}$ levels in man s. J. KONTUREK, J. BIERNAT, AND J. OLEKSY

Electron microscopic study on the jejunal mucosa in human cholera HITOSHI ASAKURA, MASAHARU TSUCHIYA, YOONOSUKE WATANABE, YASUHIRO ENOMOTO, AKIRA MORITA, TETSUO MORISHITA, HIDEO CEZAR UYLANGCO

Reaction of human small intestine to an intraluminal G. C. COOK AND R. H. CARRUTHERS FUKUMI, MAKOTO OHASHI, ANTONINA CASTRO, AND tube and its importance in jejunal perfusion studies

The liver in boutonneuse fever J. GUARDIA, J. M. MARTÍNEZ-VÁZQUEZ, A. MORAGAS, C. REY, J. VILASECA, J. TORNOS, M. BELTRÁN, AND R. BACARDÍ

Why are small bowel tumours rare? An experimental model K. C. CALMAN

Treatment of chronic hepatic encephalopathy with levodopa MICHAEL LUNZER, I. M. JAMES, J. WEINMAN, AND SHEILA SHERLOCK

Malignancy, weight loss, and the small intestinal mucosa R. E. BARRY

\section{Technique}

A rapid method of obtaining a jejunal biopsy using a Crosby capsule and a gastrointestinal fiberscope B. J. PROUT

Progress report Antitrypsin and the liver PETER W. BRUNT

Progress report Chronic hepatitis SHEILA SHERLOCK

Notes and activities

Copies are still available and may be obtained from the PUBLISHING MANAGER, BRITISH MEDICAL ASSOCIATION, TAVISTOCK SQUARE, LONDON, WC1H 9JR, price $87 \frac{1}{2} \mathrm{p}$ 